\title{
Effect of transcatheter arterial chemoembolization on cellular immune function and regulatory $T$ cells in patients with hepatocellular carcinoma
}

\author{
JUAN LIAO $^{1 *}$, JIANGWEI XIAO ${ }^{2 *}$, YUNFENG ZHOU $^{2}$, ZILIN LIU $^{2}$ and CHUNHUI WANG ${ }^{3}$ \\ Departments of ${ }^{1}$ Gastroenterology and ${ }^{2}$ General Surgery, \\ Affiliated Hospital of North Sichuan Medical College, Nanchong, Sichuan 637000; ${ }^{3}$ Department of Gastroenterology, \\ West China School of Medicine/West China Hospital of Sichuan University, Chengdu, Sichuan 610041, P.R. China
}

Received August 6, 2014; Accepted April 24, 2015

DOI: $10.3892 / \mathrm{mmr} .2015 .4171$

\begin{abstract}
The present study aimed to investigate changes in cellular immune function and regulatory $\mathrm{T}$ cells (Tregs) in patients with hepatocellular carcinoma (HCC) prior to and following transcatheter arterial chemoembolization (TACE) and their clinical significance. The proportion of $\mathrm{CD}^{+}$and $\mathrm{CD}^{+} \mathrm{T}$ cells and Tregs in the peripheral blood between healthy volunteers and patients with HCC were detected by flow cytometry prior to (1 day) and one month following TACE. The level of interleukin (IL)-35 in the peripheral blood was examined by ELISA. In the peripheral blood of patients with $\mathrm{HCC}$, the proportion of $\mathrm{CD}^{+}{ }^{+} \mathrm{T}$ cells in the total $\mathrm{T}$ lymphocytes was significantly lower compared with that of healthy volunteers $(26.71 \pm 5.57$, vs. $34.74 \pm 2.86 \%$; $\mathrm{P}<0.05)$ and the ratio of $\mathrm{CD}^{+} / \mathrm{CD}^{+} \mathrm{T}$ lymphocytes in patients with $\mathrm{HCC}$ was lower compared with that of healthy adults prior to TACE $(1.03 \pm 0.14$, vs. $1.68 \pm 0.16, \mathrm{P}<0.05)$. The ratio markedly increased following TACE treatment $(30.52 \pm 4.19$, vs. $1.29 \pm 0.14)$. The percentage of $\mathrm{CD} 4{ }^{+} \mathrm{CD} 25^{+}$Treg cells in the total $\mathrm{CD} 4^{+} \mathrm{T}$ cells isolated from the patients with $\mathrm{HCC}$ was markedly higher compared with that of healthy adults prior to TACE $(11.12 \pm 3.58 \%$, vs. $4.98 \pm 1.45 \%$, $\mathrm{P}<0.05)$ and it was significantly decreased following TACE $(7.58 \pm 2.65 \% ; \mathrm{P}<0.05)$. No statistically significant difference in the expression of IL-35 was detected prior to or following TACE in patients with HCC and healthy adults (369.66 \pm 95.53 , $352.28 \pm 107.50$ and $316.24 \pm 89.21 \mathrm{pg} / \mathrm{ml}$, respectively). The level of AFP, an oncofetal protein of $\sim 72 \mathrm{kDa}$, which is produced by normal gastrointestinal cells, yolk sac cells and
\end{abstract}

Correspondence to: Mr. Jiangwei Xiao, Department of General Surgery, Affiliated Hospital of North Sichuan Medical College, 63 Culture Road, Nanchong, Sichuan 637000, P.R. China

E-mail: xiaojiangweiabc@163.com

*Contributed equally

Key words: hepatocellular carcinoma, transcatheter arterial chemoembolization, regulatory $\mathrm{T}$ cell, interleukin-35, AFP fetal hepatocytes immediately following birth, was increased in patients with HCC $(1674 \pm 1649 \mathrm{ng} / \mathrm{ml})$ and was significantly decreased following TACE $(827 \pm 981 \mathrm{ng} / \mathrm{ml})$. Treg cells changed in positive correlation with the change of AFP, with a correlation coefficient of 0.401 . TACE markedly improved the immune function of patients with HCC.

\section{Introduction}

Hepatocellular carcinoma (HCC) is the third most common cause of cancer-associated mortality worldwide. Since China has a high incidence of hepatitis virus infection, the morbidity of HCC is significantly higher than the world average. Each year China has $\sim 110,000$ cases of mortality due to HCC (1-3). Numerous factors contribute to the occurrence and development of HCC, among which tumor immune tolerance, is of vital importance. Regulatory T cells (Tregs) are the dominant cells inducing tumor immune tolerance and thus have a significant role in the development of HCC (4-6). HCC, with a high degree of malignancy, is often in an advanced stage when it is initially diagnosed. The majority of patients have no opportunity for the tumor to be resected, and therefore, transcatheter arterial chemoembolization (TACE) is the preferred method of treatment (7). Although this method has been widely used in clinical treatment, whether it effects the expression of Tregs in patients with HCC remains to be elucidated. The present study investigated, from the perspective of tumor immunity, the impact of TACE on Tregs and the cellular immune function of patients with HCC prior to and following TACE.

\section{Materials and methods}

Patient characteristics. A total of 47 patients (40 males and 7 females; average age, $51.7 \pm 12.3$ years old) from West China Hospital (Chengdu, China) and Affiliated Hospital of North Sichuan Medical College (Nanchong, China) were collected between June 2008 and September 2011, which were diagnosed as HCC, according to clinical symptoms, imaging (CT or MRI) and AFP (an oncofetal protein of $\sim 72 \mathrm{kDa}$, which is produced by normal gastrointestinal cells, yolk sac cells 
and fetal hepatocytes immediately following birth), without anticarcinogenic drug therapy, immunostimulants or immunosuppressive agent therapy (8). Written, informed consent was obtained from the patients and the study was approved by the Ethics Committees of the Affiliated Hospital of North Sichuan Medical College (Nanchong, China) and the West Hospital of Sichuan University, (Chengdu, China).

Reagents and equipment. Mouse anti-human CD4 antibody (cat. no. EB11004873) labeled with fluorescein isothiocyanate (FITC), mouse anti-human CD25 antibody (cat. no. EB12025973) labeled with phycoerythrin (PE), mouse anti-human CD8 antibody (cat. no. EB12043197) labeled with PE-CY and the isotypic control antibody of mouse anti human immunoglobulin G1 labeled with FITC, PE and PE-CY5 were purchased from eBioscience, Inc. (San Diego, CA, USA). A flow cytometer (P07900102; BD Biosciences, Franklin. Lakes, NJ, USA) and an ELISA kit (America ADA Company, USA) were also used in the present study.

TACE. A total of $3 \mathrm{ml}$ venous blood was obtained from patients with HCC and healthy individuals with an EDTA-K2 anticoagulants mining vessel (BD Bioscience) 1 day prior to TACE and 1 month following TACE. For TACE, the Seldinger technique was used percutaneously via the right femoral artery for superselective catheter insertion into the right or left hepatic artery, which was determined by the location of the tumor (9). Subsequently, injection of lipiodol (Di Xin Chemical Co., Ltd., Wuhan, China) and chemotherapeutic drug suspension was administered through the transcatheter, which included lipiodol epirubicin (3-12 ml; Di Xin Chemical Co., Ltd.), epirubicin 30-50 mg and 5-FU (Yezhou Sheng Technology Co., Ltd., Shanghai, China; $1.0 \mathrm{~g}$ ). The dose of lipiodol and the chemotherapeutic drug were determined according to the size of the tumor and liver function condition. If the tumor diameter was $>5 \mathrm{~cm}$ the lipiodol dose was $12 \mathrm{ml}$ and the epirubicin dose was $40 \mathrm{mg}$. If the tumor diameter was $<5 \mathrm{~cm}$ the lipiodol dose was $6 \mathrm{ml}$ and the epirubicin dose was $40 \mathrm{mg}$. Gelatin sponge particles were used to embolize the hepatic artery to reduce the rate of blood flow.

Flow cytometry. The-cell surface expression levels of CD4, CD8 and CD25 were evaluated using flow cytometry, followed by incubation with FITC-conjugated anti-CD4 antibody, PE-conjugated anti-CD25 antibody and PE-CY5-conjugated anti-CD8 antibody at room temperature. FITC-conjugated mouse IgG, PE-conjugated mouse IgG or PE-CY5-conjugated mouse IgG (Becton Dickinson) were respectively incubated with the cells as a control. After $10 \mathrm{~min}$, red cells were removed using lysis buffer, and were washed once with PBS. The cells were resuspended in $0.5 \mathrm{ml}$ PBS. Analysis was performed on the results obtained from at least 10,000 cells, which were acquired on a FACSCalibur (BD Bioscience). An ELISA assay was used to determine the content of interleukin (IL)-35 in the peripheral blood, according to the manufacturer's instructions.

Statistical analysis. The data are expressed as the mean \pm standard deviation and analyzed using the SPSS 16.0 software package (SPSS, Inc., Chicago, IL, USA). P<0.05 was considered to indicate a statistically significant difference.

\section{Results}

Alteration of $T$ cell subsets in the peripheral blood of patients with $\mathrm{HCC}$. Flow cytometry of $\mathrm{CD}^{+}$and $\mathrm{CD}^{+} \mathrm{T}$ cells in the peripheral blood of patients with $\mathrm{HCC}$ and normal control individuals were compared in Figs. 1 and 2, respectively. The proportion of $\mathrm{CD} 4^{+} \mathrm{T}$ cells in the PBMC of patients with HCC was lower compared with that of the normal control group $(26.71 \pm 5.57$, vs. $34.74 \pm 2.86 \%$; $\mathrm{P}<0.05)$, while the percentage of $\mathrm{CD}^{+} \mathrm{T}$ cells was higher in the patients with HCC compared with the normal control group (25.99 \pm 4.61 , vs. $20.73 \pm 1.33 \% ; \mathrm{P}<0.05)$. The ratio of $\mathrm{CD}^{+} \mathrm{T}$ cells to $\mathrm{CD}^{+} \mathrm{T}$ cells was lower compared with the control group $(1.03 \pm 0.14$, vs. $1.68 \pm 0.16 ; \mathrm{P}<0.05)$. As shown in Table I, the patients with HCC exhibited lower cellular immune function compared with the healthy individuals.

Change of $T$ cell subsets in the peripheral blood of patients with HCC prior to and following TACE. As shown in Figs. 3 and 4 , the present study assessed the $\mathrm{CD}^{+}{ }^{+} \mathrm{T}$ cells and $\mathrm{CD} 8^{+}$ $\mathrm{T}$ cells in the peripheral blood of patients with HCC prior to and following TACE by flow cytometric analysis. The comparison between prior to and following TACE is demonstrated in Table II. The proportion of $\mathrm{CD}^{+} \mathrm{T}$ cells in the PBMCs of patients with HCC prior to and following TACE was $26.71 \pm 5.57$, vs. $30.52 \pm 4.19 \%(\mathrm{P}<0.05)$ and that of $\mathrm{CD}^{+}$ $\mathrm{T}$ cells was $25.99 \pm 4.61$, vs. $23.91 \pm 3.50 \%(\mathrm{P}<0.05)$. The ratio of $\mathrm{CD}^{+} / \mathrm{CD}^{+} \mathrm{T}$ cells was $1.03 \pm 0.14$, vs. $1.29 \pm 0.14(\mathrm{P}<0.05)$. These results demonstrated that the cellular immune function was partially restored in patients with HCC following TACE treatment.

Treg proportion in the peripheral blood of patients with $H C C . \mathrm{CD}^{+} \mathrm{CD} 25^{+}$Treg cells were detected in the peripheral blood of patients with HCC and healthy individuals by flow cytometric analysis. These results are presented in Fig. 5. The detection results of the two groups were analyzed in Table III. The percentage of $\mathrm{CD} 4^{+} \mathrm{CD} 25^{+}$Treg cells in $\mathrm{CD}^{+} \mathrm{T}$ cells isolated from the peripheral blood of patients with HCC was higher compared with the normal control group $(11.12 \pm 3.58$, vs. $4.98 \pm 1.45 \%$; $\mathrm{P}<0.05)$. The percentage of CD4 ${ }^{+} \mathrm{CD} 25$ high $\mathrm{T}$ cells in $\mathrm{CD} 4^{+} \mathrm{T}$ cells $(3.34 \pm 0.79$, vs. $1.32 \pm 0.23 \%$; $\mathrm{P}<0.05)$ was markedly higher in patients with HCC. The present study suggested that the tumor microenvironment may promote proliferation of Treg.

Influence of Tregs in the peripheral blood of patients with HCC prior to and following TACE. Flow cytometry was performed to detect the $\mathrm{CD} 4^{+} \mathrm{CD} 25^{+}$Treg cells, which were isolated in the peripheral blood of patients with HCC prior to and following TACE (Fig. 6). The percentage of $\mathrm{CD} 4{ }^{+} \mathrm{CD} 25^{+}$ Treg cells in $\mathrm{CD} 4^{+} \mathrm{T}$ cells and $\mathrm{CD} 4^{+} \mathrm{CD} 25^{\text {high }} \mathrm{T}$ cells in the peripheral blood of patients with HCC following TACE was reduced, compared with prior to TACE (Table IV). The percentage of $\mathrm{CD} 4^{+} \mathrm{CD} 25^{+} \mathrm{T}$ cells decreased from $11.12 \pm 3.58 \%$ prior to TACE to $7.58 \pm 2.65 \%$ following TACE $(\mathrm{P}<0.05)$, and the percentage of $\mathrm{CD} 4{ }^{+} \mathrm{CD} 25$ high $\mathrm{T}$ cells was reduced from $3.34 \pm 0.79 \%$ prior to TACE to $2.11 \pm 0.67 \%$ following TACE $(\mathrm{P}<0.05)$. These results demonstrated that the proportion of Treg cells in the patients with HCC 
Table I. Comparison of $\mathrm{T}$ cell subsets in peripheral blood between patients with hepatocellular carcinoma and controls (mean \pm standard deviation).

\begin{tabular}{lcrr}
\hline Group & HCC patients $(\mathrm{n}=47)$ & Healthy adults $(\mathrm{n}=15)$ & $\mathrm{t}$ \\
\hline $\mathrm{CD}^{+} \mathrm{T} / \mathrm{PBMC}(\%)$ & $26.71 \pm 5.57$ & $34.74 \pm 2.86$ & -5.343 \\
$\mathrm{CD}^{+} \mathrm{T} / \mathrm{PBMC}(\%)$ & $25.99 \pm 4.61$ & $20.73 \pm 1.33$ & 4.344 \\
$\mathrm{CD}^{+} \mathrm{T} / \mathrm{CD} 8^{+} \mathrm{T}$ & $1.03 \pm 0.14$ & $1.68 \pm 0.16$ & -15.372 \\
\hline
\end{tabular}

Table II. Comparison of T cell subsets in the peripheral blood of patients with hepatocellular carcinoma prior to and following TACE (mean \pm standard deviation).

\begin{tabular}{|c|c|c|c|c|}
\hline Group & Prior to TACE $(n=47)$ & Following TACE $(n=43)$ & $\mathrm{t}$ & P-value \\
\hline $\mathrm{CD}^{+} \mathrm{T} / \mathrm{PBMC}(\%)$ & $26.71 \pm 5.57$ & $30.52 \pm 4.19$ & -3.642 & 0.008 \\
\hline CD8 ${ }^{+} \mathrm{T} / \mathrm{PBMC}(\%)$ & $25.99 \pm 4.61$ & $23.91 \pm 3.50$ & 2.397 & 0.019 \\
\hline $\mathrm{CD}^{+}{ }^{+} \mathrm{T} / \mathrm{CD}^{+} \mathrm{T}$ & $1.03 \pm 0.14$ & $1.29 \pm 0.14$ & -8.805 & 0.000 \\
\hline
\end{tabular}

TACE, transcatheter arterial chemoembolization.
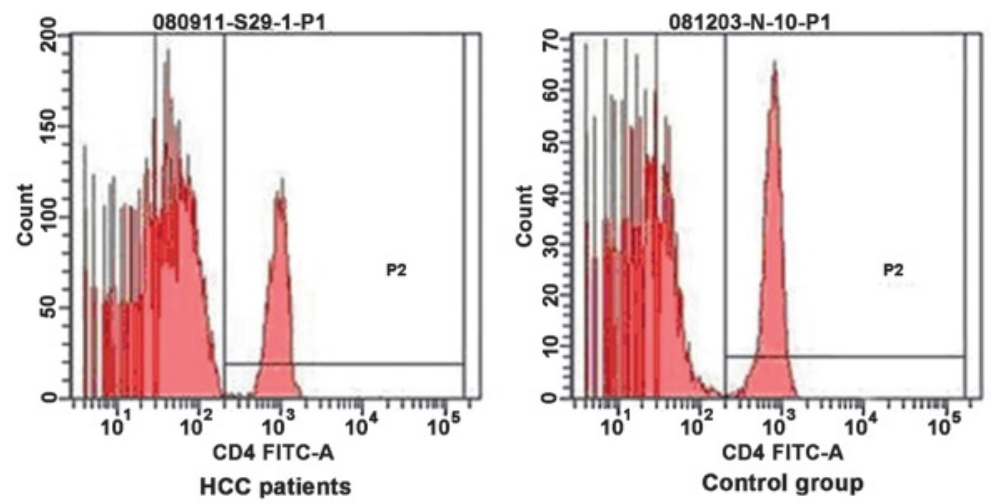

Figure 1. Flow cytometry map of $\mathrm{CD} 4^{+} \mathrm{T}$ cells in peripheral blood in patients with hepatocellular carcinoma and the control group.
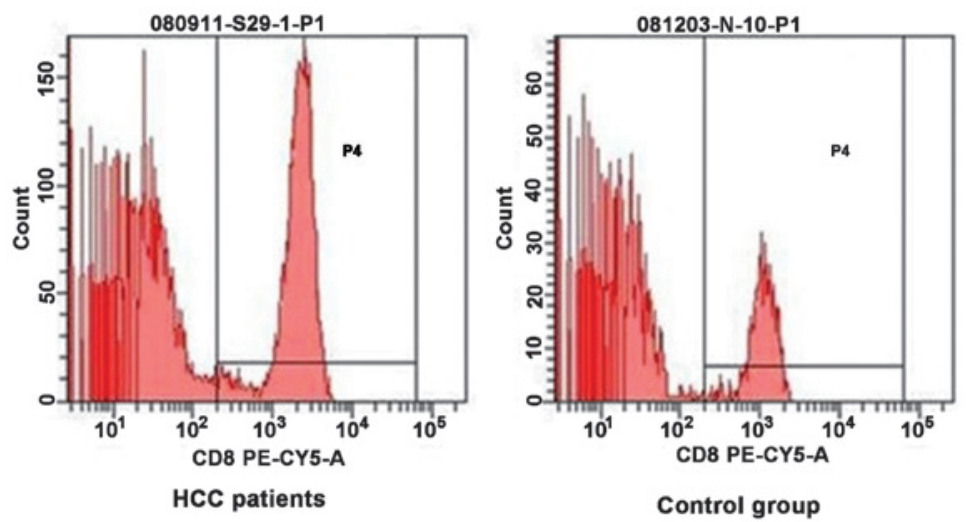

Figure 2. Flow cytometry map of $\mathrm{CD} 8^{+} \mathrm{T}$ cells in the peripheral blood in patients with hepatocellular carcinoma and the control group.

following TACE treatment decreased and its immunosuppressive function was reduced.

IL-35 in the peripheral blood of patients with HCC. The quantity of IL-35 in the peripheral blood of patients with HCC prior to and following TACE, and the healthy individuals was detected by an ELISA. The quantities were 369.66 \pm 95.53 , $352.28 \pm 107.50$ and $316.24 \pm 89.21 \mathrm{pg} / \mathrm{ml}$, respectively. The analysis revealed no statistically significant difference between the groups $(\mathrm{P}>0.05)$. 
Table III. Comparison of the percentage of regulatory T cells in the peripheral blood of patients with HCC compared with the control group (mean \pm standard deviation).

\begin{tabular}{lcccr}
\hline Group & HCC patients $(\mathrm{n}=47)$ & Healthy adult $(\mathrm{n}=15)$ & $\mathrm{t}$ & P-value \\
\hline $\mathrm{CD} 4^{+} \mathrm{CD} 25^{+} \mathrm{T} / \mathrm{CD} 4^{+} \mathrm{T}(\%)$ & $11.12 \pm 3.58$ & $4.98 \pm 1.45$ & 9.674 & 0.000 \\
$\mathrm{CD} 4{ }^{+} \mathrm{CD} 25^{\text {high }} \mathrm{T} / \mathrm{CD} 4{ }^{+} \mathrm{T}(\%)$ & $3.34 \pm 0.79$ & $1.32 \pm 0.23$ & 6.452 & 0.000 \\
\hline
\end{tabular}

HCC, hepatocellular carcinoma.

Table IV. Comparison of the percentage of regulatory T cells in the peripheral blood of patients with hepatocellular carcinoma prior to and following TACE (mean \pm standard deviation).

\begin{tabular}{lcccr}
\hline Group & Prior to TACE $(\mathrm{n}=47)$ & Following TACE $(\mathrm{n}=43)$ & $\mathrm{t}$ & P-value \\
\hline $\mathrm{CD} 4^{+} \mathrm{CD} 25^{+} \mathrm{T} / \mathrm{CD} 4^{+} \mathrm{T}(\%)$ & $11.12 \pm 3.58$ & $7.58 \pm 2.65$ & 7.883 & 0.000 \\
$\mathrm{CD}^{+} \mathrm{CD} 25^{\text {high }} \mathrm{T} / \mathrm{CD} 4^{+} \mathrm{T}(\%)$ & $3.34 \pm 0.79$ & $2.11 \pm 0.67$ & 5.302 & 0.000 \\
\hline
\end{tabular}

TACE, transcatheter arterial chemoembolization.
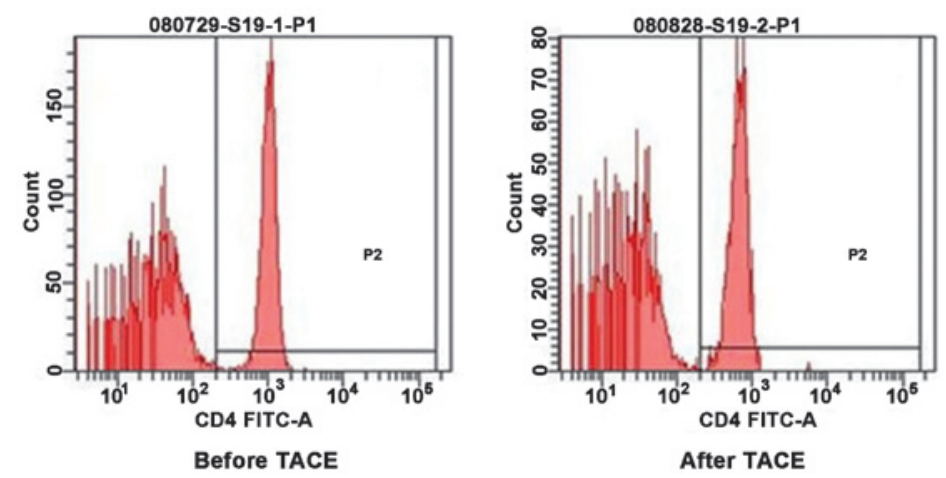

Figure 3. Index of $\mathrm{CD}^{+} \mathrm{T}$ cells prior to and following transcatheter arterial chemoembolization in the peripheral blood from patients with hepatocellular carcinoma.
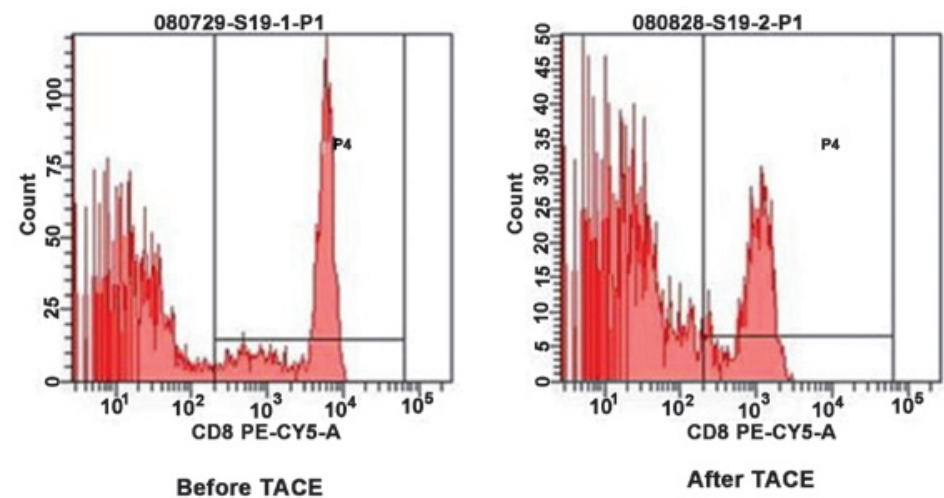

Figure 4. Index of $\mathrm{CD}^{+} \mathrm{T}$ cells prior to and following transcatheter arterial chemoembolization in the peripheral blood from patients with hepatocellular carcinoma.

Change of AFP in the peripheral blood of patients with HCC prior to and following TACE. Among the 43 patients diagnosed with HCC who were followed-up during the entire investigation, 32 patients (76.2\% of total) were positive for AFP (AFP $>20 \mathrm{ng} / \mathrm{l})$. Following TACE (1 month), the quantity of AFP was decreased to $827 \pm 981 \mathrm{ng} / \mathrm{l}$, which was markedly lower than prior to TACE $(1,647 \pm 1,649 \mathrm{ng} / \mathrm{l} ; \mathrm{P}<0.05)$. These results indicated that TACE is effective for the treatment of patients with HCC.

Correlation of index. The change in the percentage of Treg cells in $\mathrm{CD} 4^{+} \mathrm{T}$ cells and the quantity of IL-35 demonstrated 


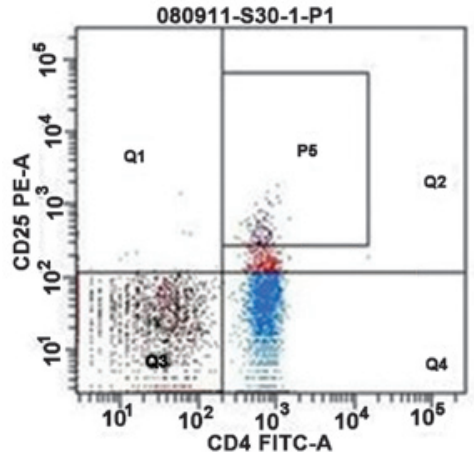

HCC patients

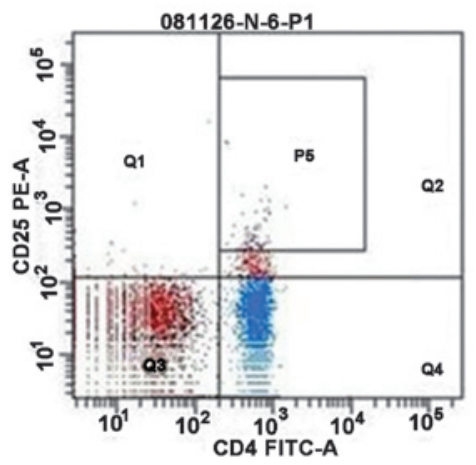

Control group

Figure 5. Percentage of regulatory $\mathrm{T}$ cells in the total $\mathrm{CD} 4^{+} \mathrm{T}$ cells between patients with hepatocellular carcinoma and the control group $\left(\mathrm{P} 5\right.$ : $\mathrm{CD} 4{ }^{+} \mathrm{CD} 25^{\text {high }}$ T cells).
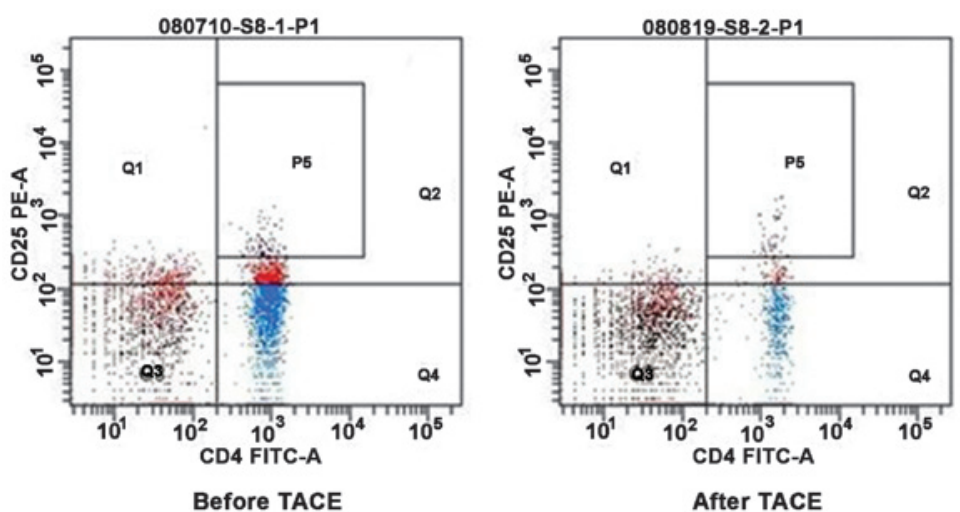

Figure 6. Percentage of $\mathrm{CD} 4{ }^{+} \mathrm{CD} 25^{\text {high }} \mathrm{T}$ cells prior to and following transcatheter arterial chemoembolization.
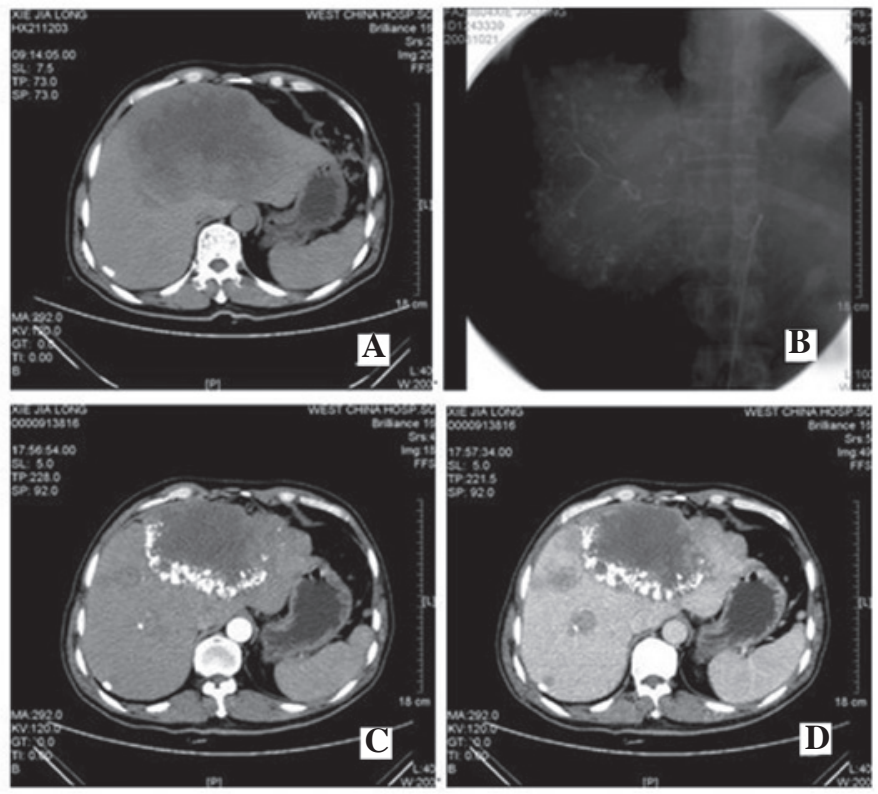

Figure 7. CT images prior to and following TACE, and images of digital subtraction angiography during surgery. (A) CT image prior to TACE; (B) Image of digital subtraction angiography during TACE; (C) CT image following TACE in arterial phase; (D) CT image following TACE in venous phase. CT, computed tomography; TACE, transcatheter arterial chemoembolization.

a positive correlation with the change in AFP $(\mathrm{P}<0.05)$, with correlation coefficients of 0.401 and 0.227 , respectively.
However, the number of Tregs and the concentration of IL-35 revealed no significant correlation $(\mathrm{P}>0.05)$. 
CT images of patients with HCC prior to and following TACE. The CT images of patients with HCC following TACE (1 month) were assessed and they displayed clear Lipiodol deposition in the tumor region (Fig. 7). A total of 30 patients with HCC underwent CT examination prior to and following TACE and follow-up results from those CT graphs were obtained. The tumors were significantly reduced compared with that prior to TACE in $17 / 30(56.67 \%)$ patients. The tumor in $10 / 30(33.33 \%)$ patients remained unchanged prior to and following TACE. The tumor in 3/30 (10\%) patients were larger than prior to TACE.

\section{Discussion}

HCC has a 5-year survival rate of $<5 \%$ and is the fifth most common type of cancer worldwide (10). There are at least 1 million novel cases per year (10). When HCC occurs, there are two antitumor mechanisms, cellular immunity and humoral immunity. The former exhibits a dominant role in the antitumor immune response. T lymphocytes, particularly, are key in immune regulation and immune surveillance during this whole process. T lymphocytes are divided into two major subsets, $\mathrm{CD}^{+}$and $\mathrm{CD}^{+}$, and the constant ratio of $\mathrm{CD}^{+} / \mathrm{CD}^{+}$ cells maintains the balance of the cellular immune response. If the ratio is significantly lower, the host immune function is weakened and this weakened antitumor effect is conducive to tumorigenesis and development (11). Several previous studies have substantiated that the immune function of patients with cancer are suppressed, which is predominantly displayed as the decrease of $\mathrm{CD}^{+}$, ratio of $\mathrm{CD}^{+} / \mathrm{CD}^{+}$and natural killer $(\mathrm{NK})$ cells; however, the changes in $\mathrm{CD}^{+}$occur at different degrees. The present study demonstrated that the proportion of $\mathrm{CD}^{+}$ cells and the ratio of $\mathrm{CD}^{+} / \mathrm{CD}^{+}$was markedly decreased, while the proportion of $\mathrm{CD}^{+}$was significantly increased in the PBMCs of the patients with HCC. These results suggested that the cellular immune function of the patients with $\mathrm{HCC}$ was weakened or inhibited.

It is important to understand how the quality and magnitude of the adaptive immune response to nonself-antigens is controlled, so as to avoid damage to the host. Tregs have an indispensable role in maintaining immunological unresponsiveness to self-antigens and in suppressing excessive immune responses deleterious to the host (12). Tregs, as major subsets of the $\mathrm{T}$ lymphocyte lineage in the healthy adult, is not only associated with tumor development, but is also important for the treatment and prognosis of the tumor (13). Immunological self tolerance is maintained, at least in part, by Treg cells, which actively and dominantly control potentially hazardous self-reactive T cells in the periphery (14). Since the majority of tumor antigens are self-antigens, the host usually maintains immunological unresponsiveness to the early primary tumor. There is a certain association between the formation of this tumor immune tolerance and Tregs. Once Tregs are activated they can suppress $\mathrm{CD} 4^{+}$and $\mathrm{CD} 8^{+} \mathrm{T}$ cells in a non-antigen-specific manner, thereby inhibiting these effector lymphocyte antitumor responses. Previous studies have demonstrated that the proportion of Tregs in the peripheral blood of patients with cancer is higher compared with that in healthy individuals. Tregs can inhibit the proliferation, differentiation and function of B cells, T helper cells and cytotoxic
T cells by the secretion of inhibitory cytokines, including IL-4, IL-10 and transforming growth factor (TGF)- $\beta$, and can subsequently directly suppress the proliferation and activity of $\mathrm{CD}^{+}$and $\mathrm{CD}^{+} \mathrm{T}$ lymphocytes, NK cells and other immune cells, which performs an immunosuppressive effect, leading to tumor immune tolerance (15-17). Other previous studies revealed that the quantity of Treg cells is increased in the peripheral blood and tumor tissue of patients with $\operatorname{HCC}(18,19)$. Among 35 peripheral blood specimens of patients with HCC, the results confirmed that the proportion of $\mathrm{CD} 4^{+} \mathrm{CD} 25^{+}$ $\mathrm{T}$ cells and $\mathrm{CD} 4^{+} \mathrm{CD} 25^{\text {high }} \mathrm{T}$ cells in the total $\mathrm{CD} 4^{+} \mathrm{T}$ cells was significantly higher compared with that of healthy adults. The number of Treg cells in the tumor microenvironment may be correlated with clinical tumor-node-metastasis stage in HCC (20), which suggested that there may be an immune mediation network in the tumor microenvironment and that Tregs are important in this network. At the early stages of tumor development, Treg cells assist tumor cell escape of the surveillance of immune cells and enable them to proliferate. Additionally, factors, including APC (macrophage cells) (21) and myeloid suppressor cells (CD14+-HLA-DR-/low $)$ (22) in tumor tissue, as well as TGF- $\beta 1$ (23) and SDF-1 (24), can also stimulate and increase the concentration of Treg cells in the tumor microenvironment. This increased level of Treg cells continues to assist tumor cells in escaping immune attack, accelerate growth and deteriorate, by inhibiting NK cells and $\mathrm{CD}^{+}$cytotoxic T cells $(15,24,25)$. Tregs and HCC reinforce each other to create a vicious cycle. If the tumor could be destroyed or excised, this cycle would be inhibited. Currently, there are several therapeutic methods, including surgical resection, liver transplantation, radiofrequency ablation, TACE and systemic chemotherapy, which prevent HCC metastasis and recurrence. Immunotherapy is an important strategy for the treatment of HCC, which may maximize the killing of tumor cells without harming normal cells.

The crucial problem with HCC immunotherapy being implemented is the low efficiency of the immune response induced. It is precisely a phenomenon, in which the Treg cells are a major factor for inhibiting the specific tumor immune response in patients with HCC patients $(26,27)$. Therefore, the induction of Treg cells may be reduced by destroying the tumor microenvironment to increase the efficacy of antitumor immune and HCC immunotherapy.

TACE is the preferred method of treatment for unresectable advanced HCC. Although TACE has been widely used clinically, it remains unclear if it may improve the immune status of patients with HCC and affect the quantity and function of Tregs. The present study demonstrated that the tumor volume of patients with HCC was substantially reduced following TACE treatment. In addition, the number of Treg cells in the peripheral blood decreased significantly, the proportion of $\mathrm{CD} 4^{+} \mathrm{T}$ cells and the ratio of $\mathrm{CD} 4^{+} / \mathrm{CD}^{+} \mathrm{T}$ cells increased by varying degrees. The Treg cells exhibited a positive correlation with the change of AFP prior to and following TACE. These results indicated that TACE improved the patients immune status and weakened the immune tolerance to increase the antitumor effects by reducing tumor burden and decreasing Tregs in the peripheral blood.

Previous studies demonstrated that Treg cells in patients with HCC performed tumor immune evasion by inhibiting 
NK cells and $\mathrm{CD}^{+}$cytotoxic T cells $(15,24,25)$. Treg cells in the tumor tissue can suppress the immunologic effector $\mathrm{T}$ cells, including $\mathrm{T}$ cells, NK cells and dendritic cells, by a variety of mechanisms. Collison et al (28) revealed IL-35 as a novel immunosuppressive cytokine, which is important in the process of native Treg immunosuppression. Whether the Treg cells in patients with HCC perform their suppression via IL-35 remains to be elucidated. The results from the present study demonstrated that the level of IL-35 in the peripheral blood is not significantly different between patients with HCC and healthy adults. The level of IL-35 revealed no significant decrease prior to and following TACE. The change in Tregs and the level of IL-35 revealed no significant correlation. Therefore, the present study cannot infer that the Treg cells in patients with HCC perform immune suppression via IL-35 in vivo.

\section{Acknowledgements}

This study was financially supported by a grant from the National Natural Science Foundation of China (no's 30700773; 81070378 and 81270561).

\section{References}

1. El-Serag HB and Rudolph KL: Hepatocellular carcinoma: Epidemiology and molecular carcinogenesis. Gastroenterology 132: 2557-2576, 2007.

2. Kew MC: Epidemiology of chronic hepatitis B virus infection, hepatocellular carcinoma, and hepatitis B virus-induced hepatocellular carcinoma. Pathol Biol (Paris) 58: 273-277, 2010.

3. Jemal A, Bray F, Center MM, Ferlay J, Ward E and Forman D: Global cancer statistics. CA Cancer J Clin 61: 69-90, 2011.

4. Pedroza-Gonzalez A, Verhoef C, Ijzermans JN Peppelenbosch MF, Kwekkeboom J, Verheij J, Janssen HL and Sprengers D: Activated tumor-infiltrating $\mathrm{CD}^{+}$regulatory $\mathrm{T}$ cells restrain antitumor immunityin patients with primary or metastatic liver cancer. Hepatology 57: 183-194, 2013.

5. Yang ZQ, Yang ZY, Zhang LD, Ping-Bie, Wang SG, Ma KS, Li XW and Dong JH: Increased liver-infiltrating CD8 ${ }^{+}$Foxp3 $^{+}$ regulatory $\mathrm{T}$ cells are associated with tumor stage in hepatocellular carcinoma patients. Hum Immunol 71: 1180-1186, 2010.

6. Yi Y, He HW, Wang JX Cai XY, Li YW, Zhou J, Cheng YF, Jin JJ, Fan J and Qiu SJ: The functional impairment of HCC-infiltrating $\gamma \delta \mathrm{T}$ cells, partially mediated by regulatory $\mathrm{T}$ cells in a TGF $\beta$ - and IL-10-dependent manner. J Hepatol 58: 977-983, 2013.

7. Han KH, Kudo M, Ye SL Choi JY, Poon RT, Seong J, Park JW, Ichida T, Chung JW, Chow P and Cheng AL: Asian consensus workshop report: Expert consensus guideline for the management of intermediate and advanced hepatocellular carcinoma in Asia.Oncology 81 (Suppl 1): 158-164, 2011.

8. Smith JA, Francis TI, Edington GM and Williams AO: Immunofluorescent localisation of human alpha feto-protein in fetal and neonatal livers and cultured cells from hepatocellular carcinoma. Br J Cancer 25: 343-349, 1971.

9. Heger N, Bayindir S, Steckenmesser R and Schirmer H: Percutaneous catheter-arteriographies: Seldinger technique. Minn Med 53: 1093-1097, 1970.
10. Motola-Kuba D, Zamora-Valdés D, Uribe $M$ and Méndez-Sánchez N: Hepatocellular carcinoma. An overview. Ann Hepatol 5: 16-24, 2006.

11. Horiguchi S, Petersson M, Nakazawa T, Kanda M, Zea AH, Ochoa AC and Kiessling R: Primary chemically induced tumors induce profound immunosuppression concomitant with apoptosis and alterations in signal transduction in T cells and NK cells. Cancer Res 59: 2950-2956, 1999.

12. Sakaguchi S, Yamaguchi T, Nomura T and Ono M: Regulatory T cells and immune tolerance. Cell 133: 775-787, 2008.

13. Ke X, Wang J, Li L, Chen IH, Wang H and Yang XF: Roles of $\mathrm{CD}^{+} \mathrm{CD} 25$ (high) FOXP3 ${ }^{+}$Tregs in lymphomas and tumors are complex. Front Biosci 13: 3986-4001, 2008.

14. Wing K and Sakaguchi S: Regulatory T cells exert checks and balances on self tolerance and autoimmunity. Nat Immunol 11: 7-13, 2010.

15. Jiang S and Lechler RI: $\mathrm{CD} 4^{+} \mathrm{CD} 25^{+}$regulatory T-cell therapy for allergy, autoimmune disease and transplant rejection. Inflamm Allergy Drug Targets 5: 239-242, 2006.

16. Fu J, Xu D, Liu Z, Shi M, et al: Increased regulatory $\mathrm{T}$ cells correlate with CD8 T-cell impairment and poor survival in hepatocellular carcinoma patients. Gastroenterology 132: 2328-2339, 2007.

17. Ghiringhelli F, Ménard C, Terme M, et al: $\mathrm{CD} 4{ }^{+} \mathrm{CD} 25^{+}$regulatory $\mathrm{T}$ cells inhibit natural killer cell functions in a transforming growth factor-beta-dependent manner. J Exp Med 202: 1075-1085, 2005.

18. Pandiyan P, Zheng L, Ishihara S, Reed J and Lenardo MJ: $\mathrm{CD}^{+}{ }^{+} \mathrm{CD} 25^{+} \mathrm{Foxp}^{+}$regulatory $\mathrm{T}$ cells induce cytokine deprivation-mediated apoptosis of effector $\mathrm{CD}^{+} \mathrm{T}$ cells. Nat Immunol 8: 1353-1362, 2007.

19. Ormandy LA, Hillemann T, Wedemeyer H, Manns MP, Greten TF and Korangy F: Increased populations of regulatory $\mathrm{T}$ cells in peripheral blood of patients with hepatocellular carcinoma. Cancer Res 65: 2457-2464, 2005.

20. Yang XH, Yamagiwa S, Ichida $\mathrm{T}$, et al: Increase of $\mathrm{CD}^{+} \mathrm{CD} 25^{+}$ regulatory T-cells in the liver of patients with hepatocellular carcinoma. J Hepatol 45: 254-262, 2006.

21. Shen X, Li N, Li H, Zhang T, Wang F and Li Q: Increased prevalence of regulatory $\mathrm{T}$ cells in the tumor microenvironment and its correlation with TNM stage of hepatocellular carcinoma. J Cancer Res Clin Oncol 136: 1745-1754, 2010.

22. Zhou J, Ding T, Pan W, Zhu LY, Li L and Zheng L: Increased intratumoral regulatory $\mathrm{T}$ cells are related to intratumoral macrophages and poor prognosis in hepatocellular carcinoma patients. Int J Cancer 125: 1640-1648, 2009.

23. Hoechst B, Ormandy LA, Ballmaier M, et al: A new population of myeloid-derived suppressor cells in hepatocellular carcinoma patients induces CD4(+) CD25(+) Foxp3(+) T cells. Gastroenterology 135: 234-243, 2008.

24. Yoshizawa K, Abe H, Kubo Y, et al: Expansion of CD4(+)CD25(+) FoxP3(+) regulatory $\mathrm{T}$ cells in hepatitis $\mathrm{C}$ virus-related chronic hepatitis, cirrhosis and hepatocellular carcinoma. Hepatol Res 40: 179-187, 2010.

25. Cai L, Zhang Z, Zhou L, et al: Functional impairment in circulating and intrahepatic NK cells and relative mechanism in hepatocellular carcinoma patients. Clin Immunol 129: 428-437, 2008.

26. Unitt E, Rushbrook SM, Marshall A, et al: Compromised lymphocytes infiltrate hepatocellular carcinoma: the role of T-regulatory cells. Hepatology 41: 722-730, 2005.

27. Zhang HH, Mei MH, Fei R, et al: The frequency, phenotypes and functions of $\mathrm{CD} 4^{+} \mathrm{CD} 25^{+}$regulatory $\mathrm{T}$ cells in hepatocellular carcinoma patients. Zhonghua Gan Zang Bing Za Zhi 15: 266-272, 2007 (In Chinese).

28. Collison LW, Workman CJ, Kuo TT, Boyd K, et al: The inhibitory cytokine IL-35 contributes to regulatory T-cell function. Nature 450: 566-569, 2007. 